Check for updates

The BMJ

Cite this as: $B M J 2020 ; 371: m 4180$ http://dx.doi.org/10.1136/bmj.m4180 Published: 29 October 2020

\section{Covid-19: Leaked documents suggest that VIPs and government contacts won PPE deals after special treatment}

Clare Dyer

Documents leaked to the Good Law Project appear to show special pathways through which "VIPs" and Cabinet Office contacts were able to win contracts to supply personal protective equipment (PPE) at the height of the covid-19 pandemic.

The non-profit organisation, along with the campaign group EveryDoctor, is mounting a High Court challenge to the UK government's decision to award lucrative contracts to companies with little or no experience in the supply of such equipment, some with links to the Conservative Party. ${ }^{1}$

In the emergency caused by the pandemic earlier this year, the government decided to award contracts totalling billions of pounds for medical supplies and hospital equipment to private companies without the usual need for competitive tender. Contracts for the supply of PPE were given to, among others, a pest control company, an employment agency, and a confectionery manufacturer.

One company-Ayanda Capital, a private family fund specialising in currency trading, offshore property, and private equity-won a £15om ( $€ 166 \mathrm{~m}$; \$195m) contract for 50 million FFP2 masks, which in the event were not used because the government decided that their fastenings were not safe enough. Ayanda has said that the masks met the government's safety specifications.

Court papers disclosed that the original approach to sell the masks came from Andrew Mills, an adviser to the UK Board of Trade and a senior board adviser at Ayanda. His company, Prospermill, which was set up in 2019 with share capital of $€ 100$ and two directors, had secured production in China. But he requested that the government sign the contract with Ayanda because it could arrange overseas payments more quickly. Mills and Ayanda told the Times in August that his position as a government adviser had played no part in the award of the contract.

\section{"Enormous margins"}

The Good Law Project said that it was aware from emails that Ayanda, which was awarded £252m for two types of masks, "were guided through the process by the Cabinet Office.” A document headed "Terms and conditions inc price" appears to state that no questions would be asked about value for money unless prices were more than $25 \%$ above average unit prices.

Jolyon Maugham, director of the Good Law Project, said, “The leaked documents reveal that Cabinet Office contacts and others were helping 'VIPs' sell PPE to government outside normal procurement channels. The information that government would buy at $25 \%$ above the price paid to regular suppliers was a licence to make enormous margins-35-45\%-on contracts sometimes worth hundreds of millions of pounds."

A government spokesperson said, "We have been working tirelessly to deliver PPE to protect our health and social care staff throughout the pandemic, with more than 4.4 billion items delivered so far and 32 billion items ordered to provide a continuous supply to the front line over the coming months. Proper due diligence is carried out for all government contracts and we take these checks extremely seriously.”

1 Dyer C. Covid-19: f150m worth of masks bought without tender by government are unusable. BMJ2020;370:m3147. doi: 10.1136/bmj.m3147 pmid: 32763894

This article is made freely available for use in accordance with BMJ's website terms and conditions for the duration of the covid-19 pandemic or until otherwise determined by BMJ. You may use, download and print the article for any lawful, non-commercial purpose (including text and data mining) provided that all copyright notices and trade marks are retained. 